\title{
The Hurons of Wendake/Lorette: A History of Intercultural Integration
}

\author{
Gabrielle Gagnon ${ }^{1}$
}

\begin{abstract}
The Hurons of Wendake are one of the rare Indigenous groups that still hold official claims to their territory in North America. Why so many Indigenous tribes failed to do the same has been extensively discussed in literature. However, little attention has been paid to the Hurons of Wendake who have maintained strong political, social, and economic power within the European dominated Saint Lawrence Valley upon their arrival in 1697. The Huron's capacity to take in the culture of their French allies to their advantage to strengthen their authority over their economy and their lands is what differentiates this group from other Indigenous nations. Their Catholic schooling system, their artwork tailored to the European's needs and preferences, as well as their sustained role as uncles of the seven fires confederacy allowed the Hurons to gain an intermediary role within North America between the settlers and Indigenous groups. This role gave them sufficient kinship ties with both Europeans and Indigenous groups to navigate through all social and economic systems coexisting at the time, and ultimately, to hold strong political, social, and economic power in the Saint Lawrence Valley.
\end{abstract}

Keywords: Hurons, Lorette/Wendake, Land Ownership, Assimilation, Moditional Economy

\footnotetext{
${ }^{1}$ Department of History, McGill University. Address all correspondence to gabrielle.gagnon@mail.mcgill.ca.
} 


\section{A Story of Dispossession and Cultural}

Misunderstandings

Indigenous dispossession of land is a phenomenon spread through America._Even though Natives were the first to inhabit the land, their view of nature as something that cannot be owned but rather can be nurtured through a relationship of mutual respect failed them when faced with the Europeans. The misunderstanding the Indigenous groups had of Europeans' capitalistic view of the land led to many groups getting manipulated into implied cessation of ownership of their land through treaties seen as opportunities to form kinship ties with their clans. Due to their distinct way of life, culture, and the novelty of the capitalist economy of the settlers, the Indigenous groups were seen as inferior by Europeans and were oftentimes not consulted in land treaties such as the Royal Proclamation of 1763.[1] These treaties negotiated large portions of land to be distributed between British and French settlers in North America while not acknowledging the claims the Indigenous nations had on these territories.[2] Considering Indigenous groups presented themselves as living in harmony with the land rather than owning it, they were perceived as having no right pertaining to territories. Europeans would meet with Native groups, smoke the calumet, and express friendship ties with them. Europeans would believe they were granted ownership of the land while these procedures only officialized partnership and loyalty between groups for the Native nations. All these factors contributed to the loss of land many Native groups suffered from the $15^{\text {th }}$ century up to this day.

However, I will argue that the Hurons of Wendake in Quebec were able to maintain a certain access to their land up to this day due to their culturally diversified education, the integration of a moditional economy within their traditional culture, and their close relationships with both the Europeans and a vast range of Indigenous allies.

\section{Cultural and Educational Integration}

First, the Huron's access to a Christian education system that they came to cherish was a beneficial factor for the groups living in Wendake/Lorette to negotiate with Europeans for their land, 
their rights, as well as trade. The Hurons had to leave their traditional territory in the1640s following the war they had with the Haudenosaunee over their homeland Huronia (Wendake Ehen) near Georgian Bay.[3] Having lost the war, the Hurons decided to move in small groups over the territory as a survival method. Even though a few settlements were found in Quebec, such as l'île d'Orléan that they called Ah8endoe ("island"), the continued raids and attacks by the Haudenosaunee, the presence of French settlers, Catholicism, and the strong links they had with other Huron groups in other territories such as Detroit led to a lot of members leaving. In 1697, the Hurons finally established themselves permanently as a group in Lorette next to their French allies, the Jesuits. Even though the Hurons were in a position of minority, representing one third of the population there, the presence of the Jesuits was beneficial for them, not only for their security if faced by an attack by the Haudenosaunee, but also for their understanding of Europeans' way of life. ${ }^{[4]}$ Even though the Jesuits' goal was ultimately to convert the Hurons to Catholicism, the Hurons perceived
Christianity as something that could be integrated into their group and their own cultural beliefs. 5$]$ Hence, by embracing the Jesuits' beliefs while maintaining their own culture, the schooling that the Jesuits offered the Hurons until 1791 helped them learn how to write and how to speak French, which gave them an advantage in negotiating with the Crown and its officers. ${ }^{6]}$

When the Jesuits left in 1791, the Hurons were aware of the autonomy that education gave them as an Indigenous group faced with many settlers and they petitioned the Crown to finance their access to school in Sillery at the Petit Séminaire de Quebec.[7] The idea that the Hurons were able to petition the Crown to offer access to education for their nation after their Jesuit allies left already shows how contact and education with the French had familiarized them with the colonial way of earning privileges. It gave them access to the resources and an understanding of the paperwork that had to be done to request privileges and claim rights that could not be done orally in amicable reunions as was done within the Indigenous communities. Even though the petition to finance schooling at Sillery 
was not a success due to the Jesuits leaving Sillery and the British encroaching on the territory where the schools would have been, they established their own local schools run by members of the community such as Sawatanen. ${ }^{[8]}$ This is an example of the way through which the Hurons were able to adapt themselves to the European system without losing their culture. In these schools, much would be taught about the colonial system (religion, language, legal systems, etc.) while still conserving Indigenous beliefs, stories, and traditions with most evaluation methods being oral, Indigenous languages being accepted within the schools, and values about nurturing nature being transmitted. ${ }^{[9]}$ Education did not simply allow greater communication and means to negotiate with settlers, it also provided them with an understanding of Europeans views of territory, which they used to their advantage. Indeed, when the Hurons noticed that the increasing group of French started invading their territory, they started buying their own portions of land called censives and had them surveyed as individual parcels of lands owned privately through notarial documents even though the lands would be used for the whole community. 110$]$ By the 1720-30s, earning censives was a common practice, and by the end of the $18^{\text {th }}$ century, the Hurons, which were a minority in the French territory, owned more acres of land per person than the French. [11] This demonstrates how their proximity to the French and subsequent access to education, which could be negatively perceived as assimilation, actually gave the Hurons an advantage in understanding how to earn things within the European system, whether it be through official documents like petitions or through earning official ownership to land. Although the Jesuits' mission was to assimilate the Hurons, the Indigenous group's openness and collaboration with the missionaries gave rise to an alliance filled with common respect. The Hurons helped the Jesuits adapt to the resources in the territory and the Jesuits helped the Hurons adapt to the colonial system. They did so by integrating school within their community, but not at the expense of their own culture and traditions that were still taught and practiced within their land. 12$]$ 


\section{A Transition to a Moditional Economy}

Second, the Hurons were able to maintain power over their land by becoming an important economic group in the Saint-Lawrence valley through the adoption of a more capitalist approach to selling their traditional craft. They first expanded their trade with the Jesuits when coming to Lorette notably in exchange for their educational services.[13] By trading with the Jesuits, they developed kinship ties with them which allowed the two groups to help one another, notably through education and knowledge about the European ways of living that the Hurons sought to know to maintain power socially and economically. Moreover, as contact kept increasing with the settlers and Jesuits, the Hurons started adapting their art, such as making moose hair embroideries by using French embroidery techniques, in order to appeal to this clientele to increase their trading power, which demonstrates their transition to a moditional economy.[14] The term moditional economy, coined by historians, describes a new and more diversified economy more focused towards profitability. They had always used tinted moose hair in art and embroideries were very important for the Hurons as it was considered an integral element of the Wendat art and was a symbol of women's power and importance within their community. But tinted moose hair and embroideries had rarely been combined before the French arrived.15] In addition, the Elgin trays were also art products sold that represented the intercultural exchange that was happening between Indigenous women and sisters from missions in Quebec. These trays were done by crafting Indigenous embroideries directly on birch bark, which was untraditional of Hurons' embroidery art usually not performed directly on birch bark, but standard practice for the sisters. The Hurons were also known for their great negotiating skills and were able to assure their right to free trade through the territory with the French and the British when they took power in $1760 .[16]$ The Hurons understood the importance and power that trading could give them and knew that by adapting their art to the Europeans, their trade could expand further than simply furs and other products derived from traditional hunting that were limited now that they 
inhabited a permanent settlement. By actively trading with the settlers, the Hurons had a privileged relationship with the Europeans, allowing them to negotiate more effectively with the settlers and to act as trusted intermediary between the settlers and Indigenous groups. 117$]$ Consequently, trading did not only increase the monetary power of the Hurons, but their social power as well. The Hurons also took advantage of Europeans' needs for supplies during the war of Austrian Succession from 1740 to 1748 to sell snowshoes, sleds, canoes, and paddles in large quantities to the Europeans. $\frac{[18]}{18}$

After the conquest of Montreal by the British in 1760, the Hurons saw more and more demand for their crafted goods and decided to take advantage of it, customizing products such as wall pockets used to hold settler's calling cards. ${ }^{[19]}$ They also profited from a flourishing souvenir market to sell traditional products like pine quillworks and moose hair embroideries to British people who wanted to give presents to their relatives back in Europe. ${ }^{[20]}$ Artwork including European details such as floral patterns also became common to appeal to the European buyers.[21] This shows that the Hurons of Lorette quickly understood the importance of entering the moditional economy brought by settlers to have more wealth and consequently, more power over their lands. They did so by taking advantage of their craftsmanship they had developed through generations of cultural practice to fulfill the settlers' needs that they analyzed and understood.

The Hurons adapted their artwork and trading style to the one of the Europeans, but they also modeled their way of profiting from territory and of its resources. The French Jesuits had given a portion of land called Quarante Arpents to the Hurons that went there to hunt and to cut wood. [22] They sold the resources on the land to earn money and charged rents for groups willing to live on it for a while. With the profit they made from these lands, the chief of the Hurons kept a fund where he compiled the money that he would spend on public expenditures such as communal lands, maintenance of buildings, community events and political activism such as legal measures to claim rights.[23] Hence, the Hurons living in Lorette not only changed their 
way of trading and their production of art to fit the economy of the settlers, but they also changed the way they dealt with the profits they got from trade, resources, and land. Even though the Hurons did not modify their beliefs, group organization (chiefs) and traditional art (embroideries), through the moditional economy, they treated their art production and land as a company they owned and would invest in which gave them superior control and power over these lands.

\section{The Uncles of the Seven Fires}

\section{Confederation}

Third, the Hurons of Lorette maintained power and privileges over their land by adapting themselves to the groups surrounding them and thus, maintaining strong alliances with both settlers and Indigenous nations. From the moment the Hurons established themselves in Lorette, they already had incredibly strong ties with the French who had helped them fight the war against the Haudenosaunee that led to the loss of Huronia.[24] The Hurons, for the sake of survival, strengthened these links further by adapting to their lifestyle by establishing a permanent settlement instead of a semi-permanent one while relying more heavily on agriculture, attending their schools where they learned more about French culture, and even adopting babies that had been abandoned by French parents near their settlement. ${ }^{[25]}$ Hurons had always been semi-sedentary, often leaving for months at a time and permanently moving big settlements every 15 years to adapt to animals' migration.[26] However, to develop strong ties with the Jesuits and to benefit from their protection, knowledge, and trade, the Hurons had to adapt and settle for good in Lorette. A lot of crossmarriage was also happening, which increased kinship ties between the two groups and the chances to cooperate with each other. Beyond that, even though Lorette was a permanent settlement, there is evidence that many Hurons were often moving around the territory to French forts and allied groups across the SaintLawrence Valley, which allowed them to keep ties with other Indigenous groups. The Hurons were part of the confederacy of the seven fires that included eight neighboring towns allied with the catholic missions along the SaintLawrence river. These nations include the 
Wendats of Detroit, the Mohawks of the Saint Lawrence Valley, and the Abenakis of the Saint Lawrence Valley. The Hurons of Lorette held great power and influence over the other groups since they were considered the uncles of the confederacy. In Native confederacies, whereas the father is often seen as a provider, the uncle is regarded as the head or chief of the said alliance. Hence, the Hurons of Lorette had a more than favorable position within their alliance. They were allies for each other through wars, political negotiations, and difficult times with resources, but also through their prior experiences with Europeans that helped the Hurons be more cautious of them and to acquire official rights for their lands and their group. [27] An example of this is the Huron's decision to add official dates or clauses of agreements on their traditional art introduced in treaty making, such as wampums, in reaction to the knowledge that their oral tradition of treaty making might not be seen as official or valid by settlers. [28] Wampums was a traditional craft made of beads offered as a testament to agreements done between two groups after important meetings occurred. These integrated patterns or drawings that symbolized the meaning of the agreement between Nations, but these patterns were not recognized as official contracts by the Europeans. Consequently, Hurons started adding official dates and clauses in Roman letters and Arabic numbers to ensure they would be recognized by the settlers. The Hurons travelling a lot also meant that they were often present at annual gatherings to renew friendship and trading ties with many communities (Indigenous and European) which gave them economic and social power as a group. [29]

Proof of the power having these social ties is their role as an intermediary between the European powers and other Indigenous groups in events such as Pontiac's war that led John Johnson, the superintendent of the Indian department, to oppose the British officials who intended to stop giving gifts to the Hurons of Lorette once the revolution was over. ${ }^{[30]}$ Their capacity to adapt to settlers while maintaining their autonomy and cultural independence is also notable through the end of the Seven Years war when they entered in communication with the British three 
days before the official capitulation because they expected the loss of the French and knew they needed to start adapting to the new situation to come.[31] They made an arrangement on September fifth, 1760, called the Murray Treaty document five, in which the Hurons of Lorette were granted the protection of their tribe at Lorette by the British Crown, their safe return to their settlement in Lorette, as well as their freedom of religion, customs and trade under the British power.[32] Having an official European paper claiming their rights to free trade and practice of customs as well as having Lorette defined as their settlement officially certainly helped the Hurons keep their claims to Lorette, unlike their claims to Sillery which was gifted by the Jesuits but that had no official paper to prove it.[33] Though the Hurons had learned how to negotiate with the British and French, they also integrated parts of their culture in by often introducing wampums and Elgin trays in arrangements with the settlers.[34] Wampums were embroideries representing their friendship and Elgin trays were often gifted as an attempt to reminisce and maintain agreements with the British after the rebellions of 1837-38 left the British considering more assimilative measures. ${ }^{[35]}$ Hence, the Huron's capacity to adopt other cultural groups within theirs and to maintain powerful ties with the seven fires confederacy and settlers (French and British) helped them acquire an intermediary status that made them very valuable to both the Europeans and Indigenous groups, giving them access to free trade and allowing them to gain claims to their land.

\section{Conclusion}

To conclude, the Hurons of Lorette/Wendake, even if restrained in a small territory today, are one of the rare Indigenous groups that were able to keep claims to their land for centuries. They did so by adapting to the arrival of settlers, their economy, their land acquisition process, and their political procedures while still maintaining strong ties to their Indigenous kinship ties and their traditional culture. By integrating French schooling, adapting their trade to settlers' needs and the capitalist economy, and managing to maintain strong ties with various groups, the Hurons of Lorette had 
the political, social, and economic strength as a group to manage their territory and defend their claims on it. 


\section{References}

Gardette Joëlle. 2014. “Les Wendats Du Québec: Territoire, Économie Et Identité, 1650-1930, Alain Beaulieu, Stéphanie Béreau Et Jean Tanguay. Éditions Gid, 2013, 340 p." Recherches Amérindiennes Au Québec 44 (1): 150-50. https://doi.org/10.7202/1027897ar.

Gettler, Brian. 2020. Colonialism's Currency: Money, State, and First Nations in Canada, 1820-1950. Études D’histoire Du Québec, 39. Montréal : McGill-Queen's University Press. http:/ / public.eblib.com/choice/PublicFullRecord.aspx?p=6237452.

Jaenen, Cornelius J. 1997. “Some Unresolved Issues: Lorette Hurons in the Colonial Context." Proceedings of the Meeting of the French Colonial Historical Society 21 : 11125. http://www.jstor.org/stable/42953213.

Labelle, Kathryn Magee, Des Chênes Jude, and Bibliothèque numérique canadienne (Firme). 2014. Le Pari De La Dispersion : Une Histoire Des Ouendats Au Dix-Septième Siècle. Québec, Québec: Presses de l'Université Laval.

Lozier, Jean-François. 2018. Flesh Reborn: The Saint Lawrence Valley Mission Settlements through the Seventeenth Century. Montréal, McGill-Queen's University Press https://www.deslibris.ca/ID/454269.

Otterbein, Keith F. 1979. "Huron vs. Iroquois: A Case Study in Inter-Tribal Warfare." Ethnohistory 26, no. 2 : 141-52. doi:10.2307/481089.

Peace, Sean Kheraj and Tom. “Document 5: Murray Treaty (1760)." Open History Seminar: Canadian History, May 29, 2019.

https://openhistoryseminar.com/canadianhistory/chapter/document-5-murraytreaty-1760/.

Peace, Thomas, and Kathryn Magee Labelle, eds. 2016. From Huronia to Wendakes: adversity, migrations, and resilience, 1650-1900. New Directions in Native American Studies 15. Norman, OK: University of Oklahoma Press. http:// site.ebrary.com/id/11259142.

The Royal Proclamation by King George III of England. October 7, 1763.

https://www.sfu.ca/ palys/The\%20Royal\%20Proclamation.pdf.

De Stecher, Annette . 2017. "The Art of Community." RACAR: Revue D'art Canadienne/Canadian Art Review 42, no. 2 : 54-71. http://www.jstor.org.proxy3.library.mcgill.ca/stable/44378615.

[1] R, George. "The Royal Proclamation," October 7, 1763

[2] R, George. “The Royal Proclamation,” October 7, 1763. 
[3] Peace, Thomas, and Kathryn Magee Labelle. 2016. From Huronia to Wendakes: adversity, migrations, and resilience,p. 74-76 \& Lozier, Jean-François. 2018. Flesh reborn: the Saint Lawrence Valley mission settlements through the seventeenth century, p.155-159, \& Otterbein, Keith F. "Huron vs. Iroquois: A Case Study in Inter-Tribal Warfare." Ethnohistory 26, no. 2 (1979), p.145-147

[4] Peace, Thomas, and Kathryn Magee Labelle. 2016. From Huronia to Wendakes: adversity, migrations, and resilience, p. 77

[5] Jaenen, Cornelius J. "Some Unresolved Issues: Lorette Hurons in the ColonialContext." Proceedings of the Meeting of the French Colonial Historical

Society 21 (1997):

[6] Peace, Thomas, and Kathryn Magee Labelle. 2016. From Huronia to Wendakes: adversity, migrations, and resilience, $\mathrm{p} .80-81$

[7] Peace, Thomas, and Kathryn Magee Labelle. 2016. From Huronia to Wendakes: adversity, migrations, and resilience, p.98-100

[8] Peace, Thomas, and Kathryn Magee Labelle. 2016. From Huronia to Wendakes: adversity, migrations, and resilience, $\mathrm{p} .80-82$

[9] Peace, Thomas, and Kathryn Magee Labelle. 2016. From Huronia to Wendakes: adversity, migrations, and resilience, p.80-86

[10] Peace, Thomas, and Kathryn Magee Labelle. 2016. From Huronia to Wendakes: adversity, migrations, and resilience,p. 76, 81-83\& Gettler, Brian. 2020. Colonialism's currency: money, state, and First Nations in Canada,p.83-87

[11] Peace, Thomas, and Kathryn Magee Labelle. 2016. From Huronia to Wendakes: adversity, migrations, and resilience, p.82-83

[12] Gardette Joèlle. 2014. “Les Wendats Du Québec : Territoire, Économie Et Identité, 1650-1930, Alain Beaulieu, Stéphanie Béreau Et Jean Tanguay. Éditions Gid, 2013, 340 p. 150

[13] [13] Peace, Thomas, and Kathryn Magee Labelle. 2016. From Huronia to Wendakes: adversity, migrations, and resilience, p. 121-123

[14] Peace, Thomas, and Kathryn Magee Labelle. 2016. From Huronia to Wendakes: adversity, migrations, and resilience, p. 94-95

[15] De Stecher, Annette. "The Art of Community." RACAR: Revue D'art Canadienne /

Canadian Art Review 42, no. 2 (2017), p.57

[16] Jaenen, Cornelius J. "Some Unresolved Issues: Lorette Hurons in the Colonial

Context." Proceedings of the Meeting of the French Colonial Historical Society 21 (1997), p. 118119 \& Peace, Sean Kheraj and Tom. "Document 5: Murray Treaty (1760)." Open History Seminar: Canadian History

[17] Labelle, Kathryn Magee, Des Chênes Jude, and Bibliothèque numérique canadienne (Firme). 2014. Le Pari De La Dispersion: Une Histoire Des Ouendats Au Dix-Septième Siècle. Québec, Québec: Presses de l'Université Laval 
[18] Peace, Thomas, and Kathryn Magee Labelle. 2016. From Huronia to Wendakes: adversity, migrations, and resilience, p.86-87, 94

[19] De Stecher, Annette. "The Art of Community." RACAR: Revue D'art Canadienne / Canadian Art Review 42, no. 2 (2017), p.58-60

[20] De Stecher, Annette. "The Art of Community." RACAR: Revue D'art Canadienne / Canadian Art Review 42, no. 2 (2017), p.59-61

[21] De Stecher, Annette. "The Art of Community." RACAR: Revue D'art Canadienne / Canadian Art Review 42, no. 2 (2017), p.60-61 \& Peace, Thomas, and Kathryn Magee Labelle. 2016. From Huronia to Wendakes: adversity, migrations, and resilience,p. 158-160 [22] Peace, Thomas, and Kathryn Magee Labelle. 2016. From Huronia to Wendakes: adversity, migrations, and resilience,p.86, 102-103\& Gettler, Brian. 2020. Colonialism's currency: money, state, and First Nations in Canada,p.164-167

[23] Gettler, Brian. 2020. Colonialism's currency: money, state, and First Nations in Canada,p.166-167

[24] Peace, Thomas, and Kathryn Magee Labelle. 2016. From Huronia to Wendakes: adversity, migrations, and resilience, p. 77-81

[25] Peace, Thomas, and Kathryn Magee Labelle. 2016. From Huronia to Wendakes: adversity, migrations, and resilience,p.96-98 \& Labelle, Kathryn Magee, Des Chênes Jude, and Bibliothèque numérique canadienne (Firme). 2014. Le Pari De La Dispersion : Une Histoire Des Ouendats $A u$

Dix-Septième Siècle.p.176-179

[26] Otterbein, Keith F. "Huron vs. Iroquois: A Case Study in Inter-Tribal Warfare." Ethnohistory 26, no. 2 (1979): 141-52

[27] Peace, Thomas, and Kathryn Magee Labelle. 2016. From Huronia to Wendakes: adversity, migrations, and resilience, p.76-77, 84-85

[28] De Stecher, Annette. "The Art of Community." RACAR: Revue D'art Canadienne / Canadian Art Review 42, no. 2 (2017), p.61-63

[29] Peace, Thomas, and Kathryn Magee Labelle. 2016. From Huronia to Wendakes: adversity, migrations, and resilience,p. 76-82\& Gettler, Brian. 2020. Colonialism's currency: money, state, and First Nations in Canada,p.178-179

[30] Peace, Thomas, and Kathryn Magee Labelle. 2016. From Huronia to Wendakes: adversity, migrations, and resilience, p. 87-90

[31] Jaenen, Cornelius J. "Some Unresolved Issues: Lorette Hurons in the Colonial Context." Proceedings of the Meeting of the French Colonial Historical Society 21 (1997), p.118120

[32] Jaenen, Cornelius J. "Some Unresolved Issues: Lorette Hurons in the Colonial Context." Proceedings of the Meeting of the French Colonial Historical Society 21 (1997), p.118120 \& Peace, Sean Kheraj and Tom. “Document 5: Murray Treaty (1760)." Open History Seminar: Canadian History 
[33] Jaenen, Cornelius J. "Some Unresolved Issues: Lorette Hurons in the Colonial Context." Proceedings of the Meeting of the French Colonial Historical Society 21 (1997), p. 120121 \& Peace, Thomas, and Kathryn Magee Labelle. 2016. From Huronia to Wendakes: adversity, migrations, and resilience,p. 75-77 [34] De Stecher, Annette. "The Art of Community." RACAR: Revue D'art Canadienne / Canadian Art Review 42, no. 2 (2017), p.58-62

[35] Peace, Thomas, and Kathryn Magee Labelle. 2016. From Huronia to Wendakes: adversity, migrations, and resilience, p.182-186 